\title{
Understanding Ethical Luxury Consumption Through Practice Theories: A Study of Fine Jewellery Purchases
}

\author{
Caroline Moraes $^{1} \cdot$ Marylyn Carrigan $^{1} \cdot$ Carmela Bosangit $^{1} \cdot$ Carlos Ferreira $^{1}$. \\ Michelle McGrath ${ }^{2}$
}

Received: 3 March 2015/Accepted: 1 October 2015/Published online: 13 October 2015

(c) The Author(s) 2015. This article is published with open access at Springerlink.com

\begin{abstract}
This paper builds on existing research investigating CSR and ethical consumption within luxury contexts, and makes several contributions to the literature. First, it addresses existing knowledge gaps by exploring the ways in which consumers perform ethical luxury purchases of fine jewellery through interpretive research. Second, the paper is the first to examine such issues of consumer ethics by extending the application of theories of practice to a luxury product context, and by building on Magaudda's ( $\mathrm{J}$ Consum Cult 11(1):15-36, 2011) circuit of practice framework. This is significant in that, to date, consumer research using practice theories has focused mainly on routine and habitual practices. Our findings and discussion provide an analysis of intentional and less intentional ethical consumer performances within the interconnected nexus of activities of consumers' fine jewellery consumption practice, where meanings, understandings and intelligibility of social phenomena are worked through the
\end{abstract}

Caroline Moraes

caroline.moraes77@gmail.com

Marylyn Carrigan

marylyn.carrigan@coventry.ac.uk

Carmela Bosangit

carmela.bosangit@coventry.ac.uk

Carlos Ferreira

carlos.ferreira@coventry.ac.uk

Michelle McGrath

michelle.mcgrath@winchester.ac.uk

1 Faculty of Business, Environment \& Society, Centre for Business in Society (CBiS), Coventry University, Priory Street, Coventry CV1 5FB, UK

2 Department of Psychology, The University of Winchester, Sparkford Road, Winchester SO22 4NR, UK various activities that shape such a practice. Finally, the paper concludes with significant managerial and policyrelated implications, as our extended circuit of practice analysis conveys that if ethics and sustainability dimensions are to be embedded in fine jewellery consumption practice, they must first be made an intrinsic part of the nexus of the social and material environment of trading and consumption places.

Keywords Consumer ethics - Luxury consumption · Marketing ethics · Practice theory - Qualitative research

\section{Introduction}

The global jewellery industry markets products which are highly valued for both their material worth and symbolic meanings (Brun et al. 2008; Danziger 2005). With global sales of $\$ 183$ billion (Dauriz et al. 2014), millions of people are employed by the global jewellery industry and some countries' entire economic wellbeing depends on this trade (Childs 2014; Cavalieri 2012). Yet the industry has faced increased criticisms from non-governmental organisations, activist groups and international governmental institutions regarding issues of corporate social irresponsibility (Lin-Hi and Müller 2013; Hilson 2008), including poor transparency, human rights abuses, child labour, money laundering, bribery and corruption, environmental degradation from mining, and funding terrorism from conflict minerals, as well as the industry's failure to demonstrate a substantial commitment to addressing these concerns and promoting ethical business practices (OECD 2013; RJC 2013a; Global Witness 2006, 2012; Human Rights Watch 2009; Childs 2010; Goreux 2001). These criticisms present significant challenges to the organisation 
of global jewellery supply chains (Earthworks 2010, 2013), as well as corporate governance (Muskawa 2014). While corporate social responsibility (CSR) has become mainstream (Baden et al. 2011), the jewellery industry is still lagging behind in their commitment to CSR (Charles 2010; Nair 2008). This issue was recently highlighted by the 2015 ICGLR-OECD-UN GoE Joint Forum on Responsible Mineral Supply Chains, which debated the challenges for downstream implementation of the OECD Due Diligence Guidance for small and medium-sized enterprises (SMEs) in four key industry sectors: jewellery, electronics, medical technology and automotives. The reticence shown towards CSR commitments may be due to the industry's composition, given that it hosts a number of SMEs and that "a tailored perspective on CSR" for small businesses with "a bespoke research agenda" (Spence 2007, p. 533) remains emergent.

Nevertheless, trade press and conferences are citing increased social responsibility as a key priority (Alawdeen 2015; Layton 2015), alongside government regulation such as the Dodd Frank Act (2010), and the European Commission Conflict Minerals draft legislation (European Commission 2013, 2014), while trade associations such as the British Jewellers' Association (BJA) and the Responsible Jewellery Council (RJC) are leading improvements in the industry's business responsibility standards at a global level (RJC 2013b; Rainer 2013). Relevant initiatives include commitments to standards of best practice, improved third-party certification procedures, supply chain initiatives that seek to enhance labour standards (Bishop 2014), and the traceability of minerals (CIBJO 2007; Kendall 2010; OECD 2013; Rainer 2013). Such organisations believe that the uncertainty caused by asymmetric information (for both businesses and consumers) in the jewellery market can be potentially reduced through the use of third-party certification (Mollenhoff et al. 2014). Although multinational corporations such as De Beers have recognised the reputational value of supporting a number of certification programmes, issues of business responsibility may not always resonate with, or represent a priority for many fine jewellery SMEs (Mollenhoff et al. 2014).

Although sales of Fairtrade and ethical fine jewellery are increasing (Hailes 2015; Bishop 2014), questions remain regarding the extent to which business responsibility may be a salient concern in consumers' choice criteria in fine jewellery purchases, as research in this area is scant. Nevertheless, rather than wait for consumers to drive a demand for jewellery CSR in order to tackle global concerns with industry-specific responsibility issues, jewellery businesses can benefit from understanding what role ethics and responsibility might play in consumers' fine jewellery purchases. Therefore, additional research on consumer ethics in fine jewellery consumption is needed. To date, research on ethical consumption-herein defined as consumer choices that go beyond economic criteria and encompass moral beliefs about animal, people and environmental welfare (Bucic et al. 2012) — has focused mainly on rational approaches to ethical decision-making (Shaw et al. 2000, 2006). Such research has also focused on the segmentation of green and ethical consumers (see Rettie et al. 2012), measurement of green markets (The Co-operative Bank 2012), and explanations for the gap between consumers' ethical attitudes and their actual consumption behaviours (Boulstridge and Carrigan 2000; Carrington et al. 2014; Chatzidakis et al. 2007; Hassan et al. 2015). Further, much research on sustainability and ethical consumption explores low-involvement, low-value product categories (Davies et al. 2012). However, issues of sustainability and responsibility impact all industries (Achabou and Dekhili 2013), and consumers will consider ethical criteria in ways that vary across different product categories (Carrington et al. 2014; Davies et al. 2012; Janssen et al. 2014). Therefore, it would be difficult to infer the extent to which ethical concerns are relevant to consumers' jewellery purchasing practices based on existing research.

This paper builds on previous research investigating ethical consumption and CSR, and makes several contributions to the literature. First, it addresses existing knowledge gaps by exploring the ways in which ethical considerations are integrated into UK consumers' highinvolvement, luxury purchases of fine jewellery. Second, the paper is the first to examine such issues of consumer ethics by extending the application of theories of practice to a luxury product context, and by drawing on and extending Magaudda's (2011) circuit of practice framework. Finally, the paper concludes with significant theoretical, managerial and policy-related implications that can shape the ongoing CSR debates in the transferable context of the global fine jewellery industry.

The paper begins with a review of the extant relevant literature on ethical concerns in consumption, the consumption of luxury goods and the practice theories approach that is used to frame our empirical work. The paper then addresses the methodology, findings and discussion, as well as the conclusions and relevant implications.

\section{Ethical Concerns in Consumption}

While some studies have approached consumption ethics through historical analyses (e.g. Newholm et al. 2014; Hilton 2003), most researchers have tried to establish a relationship between consumers' concerns with ethical issues and their purchasing decisions, the factors which 
may affect such a relationship, and ultimately whether or not it is possible to enable consumers to purchase more ethically.

Some of the most well-known rationalist approaches to the impact of ethical concerns on consumer decisionmaking are based on the theory of reasoned action (Ajzen and Fishbein 1980), which posits that consumer behaviour is a function of purchasing intention, which in turn is impacted by attitudes and subjective perceptions of norms. The theory of planned behaviour (Ajzen 1991) is another commonly used rationalist approach, which in addition to attitudes and subjective norms also includes a measure of perceived behavioural control as an antecedent to behavioural intention, in order to account for behaviours which are not entirely under consumers' volitional control. While a comprehensive review of this literature can be found in Hassan et al. (2015), research on ethical consumption using the latter theory generally produced better results than the theory of reasoned action in terms of its ability to explain and predict ethical consumer behaviour (cf. Chang 1998; Eagly and Chaiken 1995; Sparks and Shepherd 1992).

Other developments of this model entail the inclusion of values as determinants of ethical consumption behaviour (Shaw et al. 2005), but these rationalist approaches suffer from a particular limitation regarding the assessment of consumers' actions when motivated by ethical concerns (Raats et al. 1995). The models consider consumers as selfinterested agents, pursuing their own personal benefits even when social norms are considered to play a role. However, ethical concerns are more likely to include the social welfare of distant others, as well as animal and environmental issues, which are inherently driven by altruistic values (Shaw et al. 2000), and this is an acknowledged weakness in the rationalist approach to ethical consumption (Shaw et al. 2015; GregorySmith et al. 2013). Thus, research into ethical consumption has two main limitations in that it tends to consider consumer behaviour from an individualistic viewpoint and attempts to understand such phenomenon by adding variables to existing models of decision-making (Brinkmann and Peattie 2008). Such approaches are particularly problematic in the context of fine jewellery consumption, given that such a practice is motivated by emotional and symbolic drivers that go beyond rational decision-making.

Marketers have also tried to understand and cater for consumers who use their purchases as ethical votes (Moraes et al. 2011), by attempting to segment consumers according to their commitment to ethical consumption, in the belief that segmentation offers the promise of a better focus on, and understanding of, ethical consumers. However, the evidence base for segmentation as a useful tool to explain ethical consumer behaviour remains limited (Rettie et al. 2012). Researchers' profiling of responsible consumers has followed geographical, demographic, cultural, psychographic and psychological variables (Rettie et al. 2012; Gilg et al. 2005; Hines et al. 1987), but have been generally incapable of producing clear evidence that there is a segment of consumers which base all of their purchasing decisions on ethical criteria (Rettie et al. 2012). A different approach has been to produce segments based on ethical consumer attitudes rather than socio-demographic variables. For example, Finisterra do Paço and Raposo (2010) found three distinctive segments of consumers with regard to their attitudes to environmental issues, namely uncommitted, green activists and undefined. Furthermore, a recent meta-analysis highlights additional factors such as social and moral norms, as well as feelings of guilt and attribution processes, which are equally important in determining whether or not consumers will make ethical choices in the marketplace (Bamberg and Möser 2007). Thus, although useful, segmentation alone does not seem to explain ethical consumer behaviour fully.

Indeed, Rettie et al. (2012) demonstrate that consumers have no problem distinguishing between green and nongreen behaviours, but will only engage with some of those activities and not others. According to the authors, it is the degree to which an activity is thought to be normal that determines whether or not consumers will do it. They concluded that "it is possible that research attempts to identify 'the green consumer' have been unsuccessful because there is no green consumer: consumers are green in relation to some activities and not others. The identification of demographic variables relevant to green consumption may have been confounded because the demographic factors relevant to one area of consumer green behaviour are not relevant to another" (Rettie et al. 2012, p. 439). This discussion may also relate to the fine jewellery consumption context, as consumers who consider ethical criteria in other product categories may not do so in their fine jewellery purchases.

Given the points raised above, it is not surprising that so many researchers observe contradictions in ethical consumption, which have been termed the attitude-behaviour gap (Carrigan and Attalla 2001; Boulstridge and Carrigan 2000; Moraes et al. 2012; Chatzidakis et al. 2007; Hassan et al. 2015). For some time, researchers have come to expect that consumers process information about corporate social responsibility and act accordingly, favouring companies with good responsibility records and penalising those with poor ones. Such consumer actions would provide companies with incentives to 'do the right thing'; to change their actions, become good corporate citizens and receive a 'social licence to operate' from their consumers (Ferreira, forthcoming). The result would be a virtuous cycle of increased corporate profits as well as improved social and environmental outcomes (Spaargaren and Mol 1992). However, in practice, this does not seem to be the case. 
For example, Vermeir and Verbeke (2006) examine the impact of three groups of variables in the relationship between pro-ethical attitudes and the intention to acquire sustainable food products, namely involvement (the extent to which products are resonant with consumers' values and motivations), uncertainty (lack of information and knowledge), as well as perceived availability and effectiveness (perceived behavioural control). Vermeir and Verbeke (2006) find that high involvement with sustainability, certainty and perceived consumer effectiveness all have a positive impact on both attitudes towards sustainability and the intention to buy sustainable food products. Perceived low availability of sustainable products has a negative impact on the intention to buy, despite positive attitudes to the product, while social norms can explain an intention to buy, despite a negative attitude towards the product (Vermeir and Verbeke 2006).

Consumers also rationalise their attitude-behaviour gaps. Such neutralisation techniques encompass denial of responsibility, denial of injury, condemning the condemners and appeal to higher loyalties, and are employed by consumers when justifying why their ethical attitudes are not translated into ethical purchases (Chatzidakis et al. 2007). Further, d'Astous and Legendre (2009) find additional consumer arguments which justify the distance between their attitudes and actions, including the economic rationalist argument (i.e. the costs of socially responsible consumption outweigh the benefits), the economic development reality argument (i.e. economic development outweighs ethical and moral aspirations) and the government dependency argument (i.e. governments' inaction means there is no cause for alarm or action by consumers). Together, these studies highlight explanations for consumers' attitude-behaviour gaps.

Recent research highlights additional obstacles to ethical consumption. Bray et al. (2011) identify seven factors which may contribute to consumer choices that are not aligned to their manifest ethical principles, namely price sensitivity (especially for frequently purchased items), personal experience (such as habit and lack of information about the consequences of their choices), ethical obligation (including the belief that one's actions are not enough to make a difference), lack of information about ethical choices, the perceived (lack of) quality of ethical goods, inertia in purchasing behaviour (which acts as a strong disincentive to change purchasing habits even when price is disregarded) and scepticism towards companies' corporate social responsibility claims. Carrington et al. (2014) also demonstrate that four factors affect consumers' attitude-behaviour gaps, namely prioritisation of ethical issues (where primary ethical issues contribute to a sense of dissonance when non-ethical purchases take place), habits, readiness to commit to ethical consumption and types of purchasing behaviour.
Overall, ethical consumption and the analysis of consumer choice in relation to ethical concerns remain a complex task. Despite the extensive literature on rational motives driving ethical consumption decisions, the attempts to segment ethical consumers and the endeavour to understand attitude-behaviour gaps, much of the research done to date focuses specifically on low-involvement and habitual shopping. Therefore, little is known about the applicability of such studies to contexts of highinvolvement consumption practices such as those related to fine jewellery purchases, which are bound to present their own idiosyncrasies.

\section{Luxury Purchases and Ethics}

Luxury purchases have been studied since Veblen (1912), and relevant literature shows an increase in research on luxury brands (Wiedmann et al. 2009; Kapferer 2014; Han et al. 2010; Janssen et al. 2014). What might constitute a luxury product has multiple definitions, which we acknowledge (cf. Davies et al. 2012; Eckhardt et al. 2015). However, as Janssen et al. (2014, p. 46) suggest "a defining characteristic of luxury products is their scarcity or limited availability", and such products may be durable or ephemeral. Thus, for the purposes of this paper, we consider fine jewellery a luxury product given that it is a discretionary, exclusive product which is durable, scarce and of limited availability. Indeed, luxury products are marked by a set of characteristics which set them apart from necessary, everyday products or commodities in the same category. These characteristics include higher price and quality, the importance of aesthetics, the perception of scarcity versus unusualness, and various layers of symbolic meanings (Heine and Phan 2011). Such meanings, and the value of discretionary goods, are co-created by consumers and brands (Tynan et al. 2010): consumers describe luxury products in more abstract terms than necessary products (Hansen and Wänke 2011), and associate luxury products more with an experiential and symbolic dimension than with the material ownership of things (Roper et al. 2013).

Overall, luxury is associated with a positive social image (Eagly and Chaiken 1995). Whether this is the consumer's ultimate objective or not, luxury consumption can enhance status and produce benefits in social situations, including the elicitation of preferential treatment, which can be a valuable social strategy (Nelissen and Meijers 2011). Further, Han et al. (2010) propose a classification of consumers according to need for social status and wealth. The authors argue that wealthy consumers with a low need for status are interested in 'quiet' luxury goods that only other consumers like them can recognise, whereas wealthy consumers with a high need for social status prefer 
conspicuous luxury goods, which allow such consumers to convey to the less affluent that they are part of a wealthy group. Indeed, consumer research shows that consumers perceive and engage with luxury goods in ways that differ from what they do with commoditised, less prestigious products (Eckhardt et al. 2015). For consumers, luxury goods have a higher psychological distance than necessity goods, in part because of features such as perceived high quality, high price, scarcity and uniqueness (Hansen and Wänke 2011). But consumers' motivations to buy luxury goods can be intrinsic, such as the perception of superior product quality and self-directed pleasure. Psychologically, a consumer's self-esteem is an important determinant of consumption of luxury goods, which is linked positively with self-directed pleasure, but negatively with notions of conspicuous consumption (Truong and McColl 2011). Peloza and Shang (2011) provide a similar classification of the motivations behind sustainable consumption, in which CSR-related activities can be viewed as having other-oriented value (i.e. where a significant other is necessary for perceived value), or self-oriented value (i.e. where value is perceived solely for the self). Nevertheless, while research on luxury brands has increased (Wiedmann et al. 2009; Kapferer 2014; Han et al. 2010; Janssen et al. 2014), scant attention has been dedicated to the ethical issues associated with luxury consumption (Carrigan et al. 2013).

From an ethics perspective, the consumption of luxury goods has been studied as an issue of conspicuous consumption, which historically has been perceived as a moral transgression (Beckham and Voyer 2014), and associated with wasteful, lavish consumption undertaken in order to enhance the consumer's social prestige (Chaudhuri and Majumdar 2006; Godey et al. 2012). However, the concept of conspicuous consumption, with the associated normative view that luxury consumption is necessarily unnecessary and thus negative, may be an unhelpful framework with which to analyse the relationship between luxury goods and consumer ethics. In demonstrating this argument, Roper et al. (2013) describe how consumers of luxury goods present a moral framework for their consumption, in which luxury is seen as a form of restraint in consumption; a trade-off of quantity for quality (Roper et al. 2013). This same rationalisation of luxury consumption is identified by Achabou and Dekhili (2013) and Davies et al. (2012), who term it "the fallacy of clean luxuries" (Davies et al. 2012, p. 41). These findings relate to fine jewellery consumption in that consumers may well try and rationalise the purchases of such luxury items through the clean luxuries argument presented above. For example, Janssen et al. (2014) problematize consumers' perceptions of the fit between luxury and CSR concepts. Their findings suggest that, when luxury products are scarce and durable (such as fine jewellery), such products are perceived as more socially responsible than widely available ones, which in turn suggests a good fit with CSR. However, this association is not present in the case of 'ephemeral' luxury products, such as luxury fashion apparel, where the fit between CSR and luxury is considered contentious by consumers.

Further, there seems to be an ambiguous association between luxury and sustainable consumption (Beckham and Voyer 2014). For example, Davies et al. (2012) and Achabou and Dekhili (2013) suggest that prestige, price and perceptions of quality are still the most salient choice criteria in luxury product categories. Also, the inclusion of recycled materials in luxury fashion products can diminish the value of such products, as corporate responsibility remains a secondary concern for consumers, and product quality and brand reputation remain the most salient criteria for choosing luxury products in such categories (Achabou and Dekhili 2013). This is especially problematic in relation to ethical choices, as the psychological distance between consumers and luxury products means that consumers are more likely to focus on the central characteristics of the product when making their purchasing choices while ignoring peripheral ones (Hansen and Wänke 2011), such as ethical product attributes.

However, consumers are not entirely disengaged with ethical issues in luxury products. In a netnographic study of the creation and development of an online community dedicated to analysing sustainability issues in the luxury fashion sector, Cervellon and Wernerfelt (2012) conclude that knowledge about the supply chain of luxury products is important for consumers involved in eco-purchases (Cervellon and Wernerfelt 2012). These consumers derive personal benefits from the green and ethical credentials of the supply chains of the brands they buy (McEachern and Warnaby 2005). While the environmental claims of luxury products may be perceived as utilitarian, they may provide justification for consumers to increase positive evaluations of such products (Steinhart et al. 2013). But research on whether consumers consider the ethical issues in luxury purchases remains limited. To address this gap, we propose that a practice theories approach to examining consumer ethics in fine jewellery purchasing can contribute to an enhanced understanding of luxury consumption.

\section{Practice Theories and Fine Jewellery Consumption}

The approaches to the issue of luxury consumption reviewed above all start from a perspective of dualism and opposition between the individual consumer and social structures. Social theory has long been based on a central dualism of individuality versus totality, which has meant that, ontologically, many analyses have started from either 
perspective. However, this dualism has been challenged by an alternative set of understandings of human action in context, which are described as practice theories (Reckwitz 2002; Schatzki 1997). Warde (2014) argues that practice theories have emerged as an attempt to redress the shortcomings of cultural analysis, and Fuentes (2014) suggests there is much to be gained by drawing on such theories to examine ethical and green issues in consumption. Such theories highlight the complexities of cultural, social and economic processes which can impact consumption (Wheeler 2012), but they also bridge the duality between individuality and totality. Indeed, Schatzki (1990) opposes the proliferation of binaries in the analysis of social life such as individual versus social, and structure versus agency. Practices are seen to traverse individuals and structures, with an understanding that society is constituted by social practices which are produced and reproduced across time and space (Giddens 1984). Here the focus of research is the practice, understood as an ontological unit of analysis (Røpke 2009), which can be defined by the actor or the researcher (Warde 2014). While economic models see human action as dependent on individual motives and interests, and other sociological theories might tend to explain action according to the impact of social norms and the need for some consensus, practice theories seek to explain and understand action through the symbolic processes of interconnected meanings (Reckwitz 2002).

However, the proliferation of approaches which undermine dualisms in the social sciences has also meant that there is no unified practice theory approach (Warde 2014). Despite this diversity, there are commonalities between perspectives: "practice accounts are joined in the belief that such phenomena as knowledge, meaning, human activity, science, power, language, social institutions, and historical transformation occur within and are aspects or components of the field of practices" (Schatzki 2001a, p. 11). Such a field encompasses the total interconnectedness of human practices, "which can thus be demarcated as all analyses that (1) develop an account of practices, either the field of practices or some subdomain thereof (e.g. science), or (2) treat the field of practices as the place to study the nature and transformation of their subject matter" (Schatzki 2001a, p. 11). In this way, the concept of a field of practices becomes central to practice approaches (Schatzki 2001a).

In trying to describe a research agenda for the field, authors have struggled to define what constitutes a practice. Some argue that practice theory conceptualises social life as being focused on practice and, viewed from this prism, "the social is a contingent and perpetually metamorphosing array of manifolds of human activity" (Schatzki 1997, p. 284). Therefore, a practice is, first and foremost, a set of actions (Schatzki 2001b). Much of people's everyday actions are part of practices and social phenomena, such that institutions and power can be inferred from the structures and relations among practices. Thus, practices can be understood as open-ended sets of actions, connected by practical understandings, explicit rules, and teleoaffective structures, that is, orientations towards an end, how things matter and the emotions linked to such actions (Schatzki 2001b; Arsel and Bean 2013). These factors are not causes of action, but rather conditions of human existence that articulate what it is that makes sense for people to do (Schatzki 1997). And if practices are sets of actions, they depend on mental activity to take place. Thus, practices can be conceptualised as organised nexus of activities, involving both the activity and its organisation in a set of possible activities (Schatzki 2001b). It is in the context of practices that meanings are established in human life; understanding and intelligibility of social phenomena are articulated in manifolds of activity, and constitute the basic ordering medium of life (Schatzki 1997).

Warde (2005), on the other hand, distinguishes three components of practices, namely understandings, procedures and engagements, while Reckwitz (2002, pp. 249-250) describes them as "a routinized type of behaviour which consists of several elements, interconnected to one another: forms of bodily activities, forms of mental activities, 'things' and their use, a background knowledge in the form of understanding, know-how, states of emotion and motivational knowledge... a 'block' whose existence necessarily depends on the existence and specific interconnectedness of these elements". It is also possible to distinguish practice-asentity, that is, the 'gluing together' of a set of activities through material, meaning and competence (Røpke 2009), and practice-as-performance, that is, the performing of doings and sayings, thus actualising the entity (Warde 2005). Each individual is the crossing point of practices and experiences (Reckwitz 2002), managing the path dependency of daily life and participating in some practices while excluding others (Røpke 2009). In this way, practice theories focus on the systematic arrangement of meanings, know-how, knowledge, understanding, infrastructures, sayings, doings and material objects (Warde 2005; Wheeler 2012; Arsel and Bean 2013), which may or may not be carried out in socially and environmentally friendly ways (Rettie et al. 2012; Evans et al. 2012).

Practice theories have been employed in the business literature in areas as different as management science (De Clercq and Voronov 2009; Johannisson 2011; Terjesen and Elam 2009), organisational studies (Baxter and Chua 2008; Makkonen et al. 2012; Weiskopf and Willmott 2013) and marketing (Echeverri and Skalen 2011; Murphy and Patterson 2011). However, the most influential research focusing on practices has been done on topics related to consumption (Harvey et al. 2001; Warde 2005, 2014; Arsel 
and Bean 2013), and on the role of practice in understanding behaviour change towards sustainability (Evans et al. 2012; Røpke 2009; Shove and Walker 2010; Rettie et al. 2012). Indeed, this theoretical lens presents opportunities to foster behavioural change through a change in "the social and material environment of action rather than the beliefs or intentions of individuals" (Warde 2013), which is a fundamental shift in approach from the ethical consumer studies reviewed in earlier sections of this paper. Relevant works have "recognised the importance of the local setting or environment in steering behaviour, and the shared and social nature of practices" (Warde 2014, p. 297). Thus, consumers are conceptualised as practitioners-carriers of practices-rather than architects of their own action; they enact practices according to shared understandings of normality and their subjective interpretation of how to successfully perform a given practice (Evans et al. 2012). This means that (un)ethical and (non-) ecological forms of consumption are embedded in the prevailing organisation of practices and related to what people consider a normal way of life (Shove and Walker 2010; Rettie et al. 2012).

The challenge is that green and ethical attributes may not be within the inter-linkages of emotion-laden objects, doings and salient meanings, and the understandings that traverse fine jewellery consumption practices. Ethical practices in the nexus of low-involvement, habitual consumption may not 'spill over' (Thøgersen and Crompton 2009) to fine jewellery consumption, as evidenced in relevant luxury consumption studies. For example, within the organised nexus of luxury activities, Davies et al. (2012) suggest that consumer meanings do not entail the negative impact of luxury products, given the infrequency of such purchasing activities compared to commodity consumption practices; consumers have little knowledge of ethical alternatives, and co-create meanings and understandings of luxuries as items which are not produced under contentious working and environmental conditions. Further, consumers seem to understand and construe price differentials for ethical luxuries as too high, and feel they cannot research the ethical issues linked to every product they buy (Davies et al. 2012). Thus, practice-as-entity in this context is not oriented toward ethical or sustainable consumption, given that, in Røpke's (2009) words, there is no 'gluing together' of the material (i.e. luxury products), meaning (i.e. symbolic, aesthetic and hedonic rather than morally oriented) and competence (i.e. no knowledge of, or ability to search for, relevant ethical issues and ethical luxury consumption places) in the set of activities involved in luxury consumption. Therefore, ethical consumer practices entail sayings, doings and meanings in relation to routine and habitual purchases, while the ethical issues involved in infrequent consumption, such as luxury, are (perhaps unintentionally) ignored. We suggest that new practices, such as ethical forms of luxury consumption, require a process of innovation whereby consumers integrate meanings, materials and competencies in their way of doing things; they are emergent phenomena based on selforganising processes (Røpke 2009).

Thus far in consumer research, practice theories have been applied mostly to the study of low-involvement, routine and habitual purchases. This is likely a result of authors' conceptualisations of practices as routinized behaviours, as is the case in Reckwitz's (2002) work. Nevertheless, in reviewing Reckwitz's (2002) research, Everts et al. (2011) emphasise that practices consist of both routinized and intentional actions as well as many other elements, which are, to varying degrees, intentional or routinized. Therefore, if we take the broader perspective that practices entail interconnected understandings, procedures and engagements (Warde 2005), that they are an organised nexus of activities where meanings, understandings and intelligibility of social phenomena are articulated in the manifolds of activities that constitute the entire ordering of human life (Schatzki 1997, 2001b), and if we consider that non-habitual practices are also a part of such ordering of human life, then we can argue that a practice theories perspective can be applied to practices such as luxury consumption. Indeed, this argument for the use of practice theories in the context of luxury consumption is in line with Warde's $(2005$, p. 137) view of consumption through the perspective of theories of practice in that he defines consumption as "a process whereby agents engage in appropriation and appreciation, whether for utilitarian, expressive or contemplative purposes, of goods, services, performances, information or ambience, whether purchased or not, over which the agent has some degree of discretion" (emphasis added). We argue that a practices approach can shed new light on luxury consumption, including the ways in which norms and the consumption environment come into play in fostering specific types of behaviour, which, according to Warde (2014), has been neglected in accounts of practice theories. By analysing consumption through practice theories, we are forced to centre on consumption processes and to explore the ways in which practices are learned, shared, undertaken and advanced in social life, as well as how they might be dependent on complex circumstances (Wheeler 2012), including the consumption place (Everts et al. 2011).

For parsimony, we draw on Magaudda's (2011) circuit of practice framework, which has been previously utilised in the context of music consumption (Magaudda 2011), and home design (Arsel and Bean 2013). Based on Shove and Pantzar's (2005) practice scheme, Magaudda's (2011) circuit of practice is an analytical framework designed to 
assist in the analysis of a practice and changes in such a practice. The framework entails three key elements, namely object, doing and meaning, which constitute the practice (in our case, fine jewellery consumption), and which helps to explain the dynamics of such elements within a practice from the viewpoint of consumers' specific experiences. According to Magaudda (2011, p. 21), the circuit is "both an analytical and visual tool to account for the work of reconfiguration of the practice as actually experienced by consumers, focusing on the individual and concrete level in which practices are created, stabilized and transformed". Further, we add to the circuit of practices framework by giving additional emphasis to the role of norms, shared knowledge and understanding, as well as experience of the local consumption setting or place (Everts et al. 2011; Warde 2014), in order to acknowledge the ways in which practices are understood, shared, performed and advanced in the case of fine jewellery consumption. The methodology is discussed next.

\section{Methodology}

Interpretive research seeks to gain in-depth understanding of a particular phenomenon or behaviour, and to generalise to theoretical propositions rather than to populations (Jamali et al. 2009; Carrigan et al. 2011). We used an interpretivist approach to explore the subjective meanings and understandings (Bryman and Bell 2011; Spiggle 1994), which interconnect participants' nexus of fine jewellery consumption practices. A qualitative approach was considered appropriate given the exploratory nature of the research at hand (Cresswell 2007; Miles et al. 2014), and the dearth of investigation on fine jewellery consumption. The snowballing technique, which is an acceptable sampling strategy in qualitative research (Patton 1990; Kuzel 1999; Crouch and McKenzie 2006), was used to recruit participants who had prior experience of purchasing jewellery at the Birmingham Jewellery Quarter (BJQ). Being a consumer of fine jewellery was a necessary characteristic of the sample, which afforded in-depth understanding of relevant consumption practices for this research. The call for research participants was posted on a UK university's web portal and aimed solely at staff. Although most research participants were recruited through this call, additional participants were selected through the personal networks of participating staff (Table 1).

We recruited both male and female participants who shop in the BJQ, and their demographic profiles reflect UK fine jewellery consumers more generally (Keynote 2014). As the location of one of the main UK Assay Offices, as well as a number of fine jewellery SMEs trading locally and globally (Pollard 2004; de Propris and Wei 2007), the
Table 1 Participants' profiles

\begin{tabular}{|c|c|c|c|c|}
\hline & Pseudonym & Age & Income $(\mathfrak{f})$ & Education \\
\hline 1 & Jane & $26-35$ & $20,001-30,000$ & Postgraduate degree \\
\hline 2 & Jill & $36-45$ & 50,001 and above & Postgraduate degree \\
\hline 3 & Dean & $56-65$ & 50,001 and above & Postgraduate degree \\
\hline 4 & Barbara & $46-55$ & 50,001 and above & Postgraduate degree \\
\hline 5 & Zana & $16-25$ & $10,001-20,000$ & Further education \\
\hline 6 & Jonathan & $46-55$ & $40,001-50,000$ & $\begin{array}{l}\text { Undergraduate } \\
\text { degree }\end{array}$ \\
\hline 7 & Keith & $26-35$ & $30,001-40,000$ & $\begin{array}{l}\text { Undergraduate } \\
\text { degree }\end{array}$ \\
\hline 8 & Dennis & $26-35$ & $10,001-20,000$ & Postgraduate degree \\
\hline 9 & Steve & $26-35$ & $30,001-40,000$ & Postgraduate degree \\
\hline 10 & Roy & $16-25$ & $30,001-40,000$ & Postgraduate degree \\
\hline 11 & Tamira & $46-55$ & $10,001-20,000$ & Further education \\
\hline 12 & Kieron & $36-45$ & $30,001-40,000$ & Postgraduate degree \\
\hline 13 & Thomas & $26-35$ & $30,001-40,000$ & Postgraduate degree \\
\hline 14 & Felix & $26-35$ & $30,001-40,000$ & Postgraduate degree \\
\hline 15 & Alex & $26-35$ & $30,001-40,000$ & Postgraduate degree \\
\hline 16 & Janet & $46-55$ & $20,001-30,000$ & $\begin{array}{l}\text { Undergraduate } \\
\text { degree }\end{array}$ \\
\hline 17 & Harriet & $55-65$ & $30,001-40,000$ & Postgraduate degree \\
\hline 18 & Violet & $26-35$ & $20,001-30,000$ & $\begin{array}{l}\text { Undergraduate } \\
\text { degree }\end{array}$ \\
\hline 19 & Helen & $46-55$ & $20,001-30,000$ & Further education \\
\hline 20 & Linda & $36-45$ & $30,001-40,000$ & Postgraduate degree \\
\hline
\end{tabular}

BJQ is a significant fine jewellery market. As an industry cluster, the BJQ is a microcosm of the wider jewellery marketplace, enabling an informed snapshot of fine jewellery consumption practices. The sample yielded a total of twenty semi-structured, face-to-face interviews, which lasted approximately one hour each. This small number of interviews is consistent with prescribed approaches to finegrained, in-depth inquiry (Sen and Crowley 2013; Crouch and McKenzie 2006). The interviews allowed participants to introduce and reflect on issues and practices that they perceive as relevant to the research topic (Kvale 1996). Although practice theorists have been criticised for their lack of methodological prescription (Warde 2014), the use of in-depth interviews is in line with a practice theories approach (cf. Magaudda 2011; Arsel and Bean 2013; Wheeler 2012). As Wheeler (2012) suggests, although it may seem uncommon to explore practices through individual interviews given that practices are understood as complex bundles of interconnected elements, the individual is still at the cross-point of practices (Wheeler 2012; Reckwitz 2002). As such, it is through the individual's mental and embodied performances that we can understand practices that are intertwined with consumption.

Participants loosely discussed shopping trips to the BJQ and reflected on their fine jewellery purchases including the 
jewellery objects they bought, reasons for which jewellery was purchased, the meanings of such jewellery and their experiences of the BJQ. Individual participant's answers were then probed further with a view to gaining in-depth insight into interrelated practices. Additionally, given our research involvement with SMEs in the jewellery industry, which included a series of private industry meetings and discussions, trade shows and events between 2011 and 2014, we gained a wider perspective on jewellery markets, industries, institutional environments and regulatory contexts. Although such SME research findings are not within the scope of this paper, they have influenced our analysis of the consumer practices we analyse here.

All interviews were voice-recorded and transcribed verbatim to address issues of credibility (Lincoln and Guba 1985). Data analysis was ongoing throughout the project and followed a thematic analysis approach (King and Horrocks 2010; Bryman and Bell 2011). Initially two authors took a few transcripts and coded them independently. Then they compared codes, agreed on which codes seemed to reflect the data best before analysing more scripts and comparing them again. NVivo10 software was used to support this iterative process, which led to the emergence of a coding scheme including relevant analytical themes (King 1998). As the analysis progressed more detailed codes emerged, which in turn were organised according to, and building on, Magaudda's (2011) circuit of practice framework. Moreover, we decided to use a writing strategy which focuses mainly on two key narrative cases derived from the findings, which is consistent with the manner in which previous studies using practice theories have represented their in-depth findings (Wheeler 2012; Magaudda 2011). Through this writing strategy, we examine and highlight the most relevant as well as the most exceptional elements (Bazeley 2013) of fine jewellery consumption practice. In this way, we prioritise depth of insight and narrative over a theme-by-theme description, which in turn allows us to preserve the holistic nature of a few in-depth accounts (King and Horrocks 2010; Saunders et al. 2009). Finally, we sought interpretive quality by considering the study's theoretical frame and contributions, comparing and discussing interpretations, respecting participants' sayings and doings, and providing evidence of the emerging interpretations (Pratt 2009; Moraes et al. 2014).

\section{Findings and Discussion}

We draw mainly on two purposefully selected extended narrative examples concerning fine jewellery consumption practice, which illustrate whether and how ethical performances and meanings may or may not be involved in such a practice. The first example entails the practice dynamics involved in the purchasing of a conflict-free diamond ring, which embodies ethical performances in fine jewellery consumption practice. The second consists of an analysis of redesigned fine jewellery consumption where ethical meanings are not as salient as in the first example. Conflictfree sourcing and recycling are central tenets of such accounts. In each example, we discuss the three key elements of Magaudda's (2011) circuit of practice framework (i.e. object, doing and meaning). However, in our extended framework (Figs. 1, 2), norms, shared knowledge and understanding, and experience of the consumption environment or place (Everts et al. 2011; Warde 2014) are also emphasised in order to explain the dynamics of such elements within the fine jewellery consumption practice from the viewpoint of consumers' experiences and narratives. Relevant themes within these elements are also highlighted and analysed. In our extended fine jewellery circuit of practice (Figs. 1, 2), we assume a constant, constitutive relationship between all core elements of the framework, with norms, shared knowledge and understanding, and experience of the consumption place seen as part of that relationship and of the field of fine jewellery consumption practice. Further, and following Magaudda (2011), the lines in the figures indicate consumers' specific experiences of the relationships between such elements as they manifest in fine jewellery consumption. Through this presentation of the findings and discussion, we seek to bring to the fore and make explicit the intertwined and organised nexus of activities, understandings, rules, and emotions linked to the jewellery practice (Schatzki 2001b; Arsel and Bean 2013), and to highlight opportunities to foster behavioural change through a change in the social and consumption environment (Warde 2013) of jewellery purchases.

\section{Caring About Fine Jewellery Ethics: The Conflict- Free Diamond Ring}

We draw on the example of the conflict-free diamond ring in order to illustrate how ethical performances can be a part of consumers' fine jewellery consumption practice. Through this example, we convey the ways in which consumers can interact, and develop new connections, with ethical fine jewellery objects. Our analysis suggests such ethical performances are far from widely spread across our sampled research participants. However, this exceptional example is useful and significant in that it allows us to conceptualise what can happen when ethical performances, meanings and the consumption place come into play within fine jewellery consumption practice, and how they can foster ethically resonant, innovative reconfiguration of objects, meanings and doings within the practice. 
Fig. 1 The extended circuit of practice of an ethical diamond ring

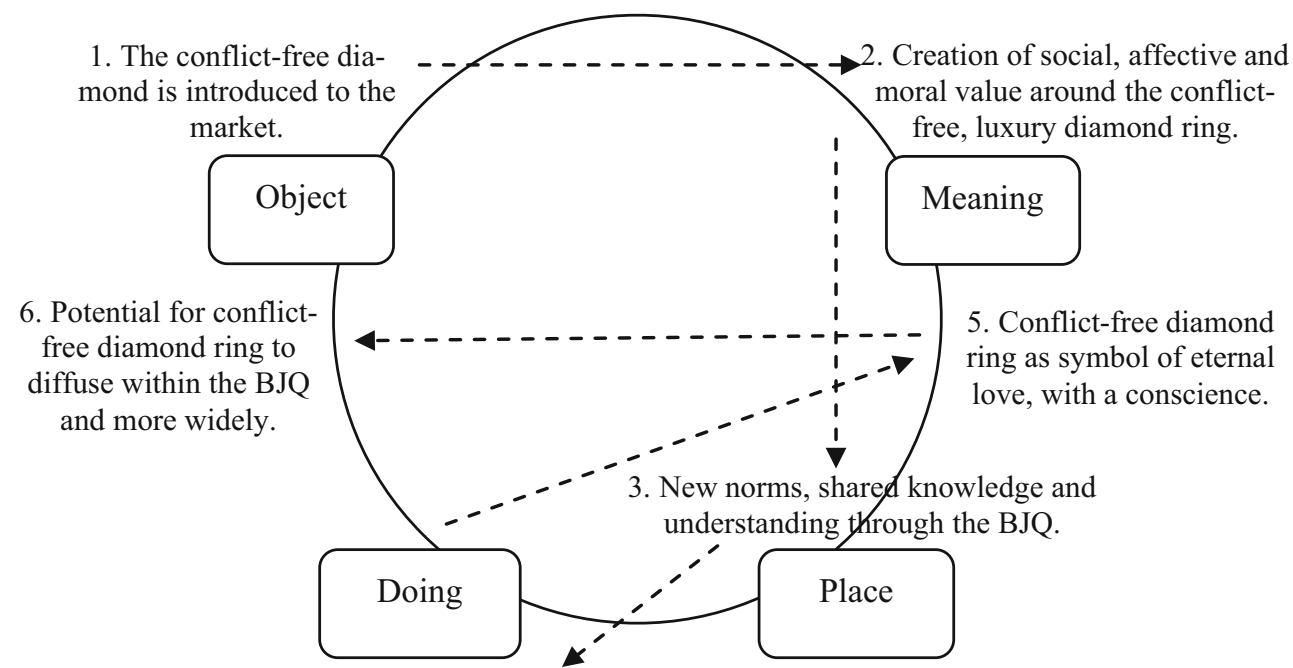

4. Purchasing the conflictfree diamond ring.

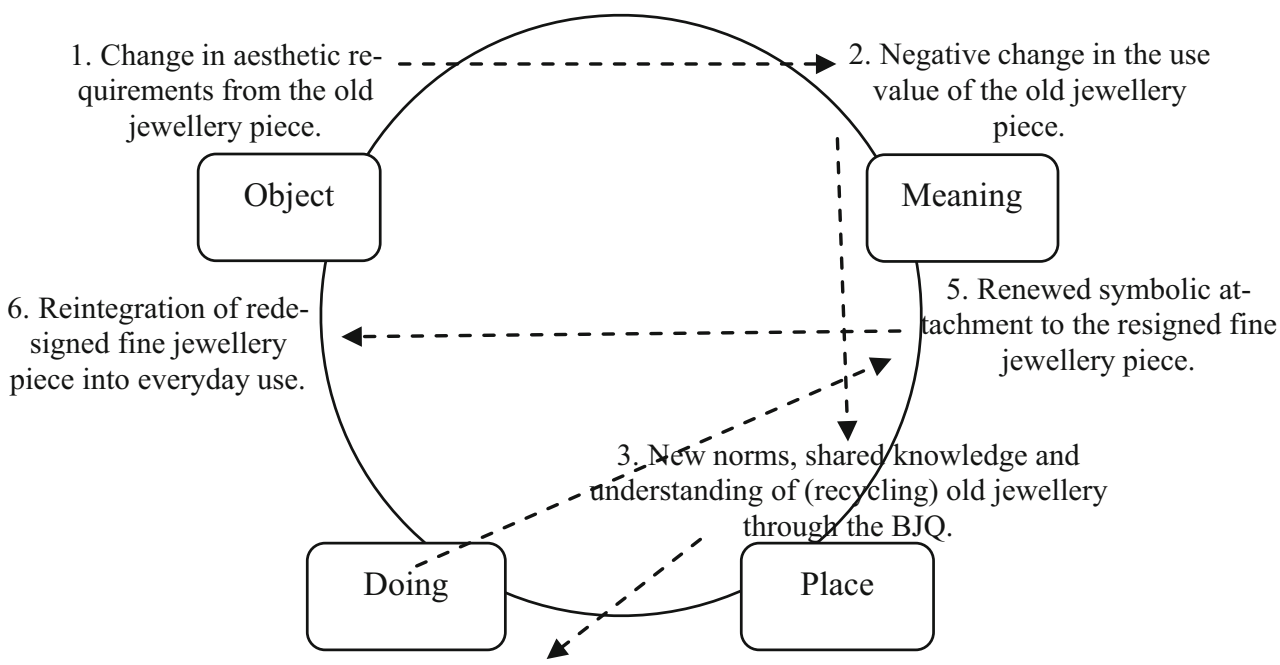

4. Acquisition of new abilities in redesigned and recycled fine jewellery; acquisition of the actual redesigned piece.
The conflict-free diamond ring is an object which represents the reconceptualization of the fine jewellery consumption practice through ethical meanings that can have cultural, economic and social impacts. Although not a new object as such, the conflict-free diamond ring can enable consumer appropriation and meaning redefinition in a potentially paradoxical and, to date, incommensurable way in the minds of most consumers (i.e. through luxury plus ethics). Alex's account of buying his wife's engagement ring in the BJQ illustrates these points:

I bought my wife's engagement ring in the BJQ, back in 2007. My main focus was... It had to be a conflict- free diamond. That was my big, big ethical dilemma when I was buying it. Apart from that, it was just then the style that she would like, but the conflict-free... The diamonds need to be able to be traced back to their location and source and obviously, if they're not, then there's a big chance that they are being used to fund all sorts of corrupt terrorist regimes... And something as valuable and as important as diamonds in our society should be able to be traced, I think, and shouldn't be used to be funding wars and conflicts... I don't know much about Fair Trade jewellery, [but] I know a big supporter of the Fair Trade movement itself through my family, through my family's church 
and things, and just through my general ethical outlook. I am a big supporter of Fair Trade. I try and buy it wherever possible... I was literally walking into shops and my first question wasn't looking at the rings, it was, are your diamonds conflict-free, can you prove it? If they answered yes to both those questions, then I'd have a look. If not I left straight away, went to the next one. They were very friendly and helpful... They had the styles we liked, at the price that was agreeable. In the BJQ there's a cluster of jewellers around and you can go from place to place finding the one I wanted with the background I wanted (Alex, 26-35 age bracket).

During the interview, Alex also discussed how much he loves his wife and how much he wanted to convey his love through the diamond ring without harming anyone down the supply chain. Alex's account reveals prioritisation of ethical issues (Carrington et al. 2014), and factors (e.g. shops without ethical diamonds or lacking in proof of traceability, time-consuming search process due to prioritisation of ethical concerns) which could have contributed to a consumer choice that was not aligned to Alex's manifest ethical principles (Bray et al. 2011), if Alex were not so adamant about the importance of the conflict-free attribute (i.e. having to expend considerable search effort before finding a jeweller offering conflict-free rings). Alex's case also shows many different elements of, and steps in, the fine jewellery consumption circuit of practice (Fig. 1) including the processes involved in the appropriation (i.e. the ethical thinking, sayings, doings and places involved in the purchase) of the conflict-free diamond ring, and meaning redefinition (i.e. the diamond as the signifier of ethical love without harmful impact, rather than the signifier of love through luxurious aesthetic beauty without a conscience), which reconciles luxury and ethics through the material object. This addresses the ambiguous association between luxury and responsible consumption (Beckham and Voyer 2014), and reinforces the fit between luxury and CSR, aligned with Janssen et al.'s (2014) view that durable luxuries are more resonant with sustainability concerns. The range of designers and custom design capabilities of the BJQ, the BJQ as the consumption place (Warde 2014; Everts et al. 2011), norms (Rettie et al. 2012) in relation to such a ring, and consumers' shared knowledge and understanding of the BJQ further enable this consumer appropriation of the conflict-free diamond ring through direct, place-based interactions with fine jewellery designers and diamond dealers. In this way, the quote above highlights the interrelated articulation of object (steps 1 and 6-the diamond ring, which is now 'conflictfree'), meanings (steps 2 and 5-the social, affective and moral value of the conflict-free ring and its symbolic dimensions) and ways of consuming (step 4-the purchasing processes and the actual purchase) in relation to the conflict-free diamond ring, as illustrated in Fig. 1.

Additionally, by drawing on our extension of Magaudda's (2011) circuit of practice, Alex's account demonstrates the importance of norms (i.e. the influence of family, church and relevant Fairtrade supporter), shared knowledge and understanding and, as Everts et al. (2011) and Warde (2014) suggest, experience of place and consumption environment (i.e. learning about conflict-free diamond by researching and engaging with BJQ; step 3). Indeed, the interrelatedness between elements of the fine jewellery consumption practice highlights the potential for fostering a more normalised link between consumer ethics and luxury products through the consumption place (i.e. the retail environment). Through our extension of Magaudda's (2011) circuit of practice framework, it is also possible to identify the complex connection between different practices (Warde 2005), namely conflict-free diamond ring and Fairtrade support in other product categories, which is developed through norms, shared knowledge and understanding of domestic consumption ethics generally. We can thus explain Alex's case above in relation to the everchanging and complex relationships among the object, doings and representations (Schatzki 1997), and the sets of fine jewellery consumption actions that are connected by practical understandings, explicit rules and teleoaffective structures (Schatzki 2001b; Arsel and Bean 2013).

In examining ethical dimensions in our participants' fine jewellery consumption practice, it is possible to argue that the availability of conflict-free diamonds has been coupled with relevant shared knowledge (anecdotal or otherwise) about the ethical issues linked to diamonds as conveyed by various media. For example, most participants mentioned the issue of blood diamonds as seen in films and due to celebrity scandals, as well as news exposés on labour and other human rights issues. This is in line with research which suggests that knowledge about the supply chain of luxury products can be important in consumers' ethical purchases (Cervellon and Wernerfelt 2012; McEachern and Warnaby 2005). Such knowledge and availability of conflict-free diamonds, in turn, has enabled some consumers such as Alex and Thomas below to articulate new practices, meanings and involvement with fine jewellery (Sethi and Glozer 2013):

It's an 18 carat rose gold ring with an engraved pattern going all the way around it. She loves it. I told her that I designed it. The designer also gave me some professional sketches of the ring. I designed it all over Skype with the designer so I would have probably one or two Skype sessions a week... I bought the diamond separately... For this particular 
ring I would say, umm... I would say the location for the diamond was quite important because I think, when you buy something like that, it has to be, for me anyway, it has to be personal so I have to have seen it and had personal interaction with it and chosen it from a range of diamonds, so it was obviously important for me to be close to that. The metal, particularly the colour of the metal, that's obviously very important to me and the engraving is very important. I don't actually know how Fair Trade affects suppliers. The ethical part of jewellery supply that I know about is the diamond... The Kimberley Process. Obviously when I went through my engagement ring thing, I read up on the Kimberley Process and the UN's actions around this and all of that sort of stuff, so I became quite informed. I know that it's fairly standard now; it's a fairly standard practice, that jewellery diamonds would be sourced through the Kimberley Process... And I know that there're certificates that you can get for each diamond to prove that it's been sourced ethically and sustainably, that sort of thing, but I don't know the details of the process... I actually requested the invoice from the retailer so the retailer had bought it off a wholesaler and the wholesaler had put on the receipt that it was guaranteed from the... I think it was guaranteed to meet the UN Convention on... The receipt actually acts as a certification that it's been through the Kimberley Process... That's quite important to me. I had a designer who was kind of looking after me... I got advice from them on what was important in a diamond and one of those things was that, actually, the designer I was working with refused to work in any way with diamonds that weren't $100 \%$ certified to have gone through the Kimberley Process, so I made sure... It was kind of in my interest to make sure that the diamond I got came through that process (Thomas, age bracket 26-30).

Thomas's account also illustrates how our extended version of Magaudda's (2011) framework (Fig. 1) captures the way in which the object (i.e. conflict-free diamondstep 1) and the certification of its ethical credentials (the Kimberley Process-step 2) can be embedded in the infrequent yet meaningful purchase of fine jewellery. The quote shows Thomas's considerable efforts in personally creating meanings (i.e. social, affective and moral—step 2) and symbolic value (i.e. love with a conscience-step 5) for his purchase. This is achieved through the design of the ring, the selection of materials and the competences involved in the purchasing process (i.e. actualising the purchase-step 4). Further, the consumption environment or place (i.e. the BJQ, where the designer was based and where the conflict-free diamond was bought—step 3) plays a major role in the practice, and the designer, in particular, also nudges Thomas to buy the conflict-free diamond (i.e. diffusion of conflict-free attribute in the market-step 6). Thus, the extended circuit of fine jewellery consumption practice must be recognised in market attempts to introduce ethics in this context. The recently launched "I do" campaign of the Fairtrade Foundation (2015) is such an attempt to encourage consumer ethics in fine jewellery consumption practice, as are other retail and designer initiatives such as "Arctic Circle", an ethical jewellery brand combining Fairtrade gold and fully traceable Canadian diamonds (Jordan 2015).

Admittedly, for most participants, ethical considerations are just not part of the fine jewellery purchasing practice, and the 'non-ethical' diamond ring remains a powerful symbol of rituals (e.g. engagements, marriages, birthdays, and special occasions), love (e.g. the assertion of affectionate attachment to a special person) and luxury (e.g. social status, distinction). Such symbolic dimensions are as yet rarely accompanied by ethical considerations. Nevertheless, we argue that the conflict-free diamond ring has the currently unrealised potential not only to penetrate the fine jewellery consumption market further, but also to open up the marketplace for additional ethical objects of fine jewellery, such as pieces incorporating ethical precious metals and other responsibly sourced coloured gemstones.

New practices such as ethical luxury consumption require a self-organising innovation process through which consumers integrate norms, meanings, materials and competencies in their ways of doing things (Røpke 2009), where the ethical object, such as the conflict-free diamond ring, acquires relevance in pre-existing social practices (Magaudda 2011), which are dependent on complex circumstances (Wheeler 2012), including the consumption environment and place (Everts et al. 2011; Warde 2014).

\section{Unintentionally Ethical: Consuming Redesigned Jewellery}

Unlike the conflict-free diamond ring, redesigned jewellery was the most widely consumed object among our participants, so it was chosen as the second example to illustrate the extended circuit of fine jewellery consumption practice. There are two aspects which make redesigned jewellery a relevant object for our study. First, old jewellery pieces tend to have old-fashioned designs and, although valued for their emotional, symbolic and luxury dimensions, including perceived high quality, high price, scarcity and uniqueness (Hansen and Wänke 2011; Heine and Phan 2011; Davies et al. 2012; Achabou and Dekhili 2013), they usually do not resonate with consumers' personal aesthetic tastes. Participants often spoke of getting their heirlooms 
redesigned so that they could wear such pieces of fine jewellery rather than leave them unused, as illustrated in the quote below:

I've had different bits of jewellery, like, that was more keepsake jewellery and it was just sitting in a box and I wasn't really using it. And then I had a ring bought for me when my Nan passed away, and it was a solitaire. And then when I got engaged, I didn't want to wear two solitaires, but then I didn't want to just have it sitting in the drawer doing nothing, so I had them all... I had bits from my 18th, 20th... so I just had it melted down and all put together, so it was all in one, as opposed to lots of bitty bits everywhere (Violet, 26-35 age bracket).

As seen in Violet's quote, the reintegration of the old jewellery into current fine jewellery consumption practice demonstrates the route of an object that once lost its perceived use value for our consumer. But it also illustrates the second aspect which makes redesigned jewellery a relevant object on which to focus here, which is that getting an old piece of fine jewellery deliberately redesigned unintentionally entails recycling the precious stones and fine metals of the original jewellery piece. This goes counter previous literature, which suggests that the inclusion of recycled materials in luxury products diminishes the value of such products (Achabou and Dekhili 2013), and participants did not allude to the fallacy of clean luxuries (Achabou and Dekhili 2013; Davies et al. 2012). This may be a result of two dimensions which are specific to fine jewellery practice. The first is that our participants do not associate sustainability with redesigned fine jewellery pieces:

...Everyone's heard about sustainability with regards to materials such as plastics, woods, metals, in terms of more like heavy goods, with metals... But I think it's a bit of an alien idea for the public with regards to jewellery because it's always just been there (Dennis, 26-35 age bracket).

Well, we recycle... Not necessarily for ecological reasons, but for you know... For what that piece of jewellery may mean... Then we've recycled scrap bits of... I say scrap bits of gold, that are no longer useful, and obviously that's been bought by people in the BJQ... In some of the things that we've had made there, they've used existing sort of gold or whatever we may have, that's sort of been handed down through the family, so that has a meaning in itself, just being able to use old rings or necklaces or earrings or whatever it is and reconstruct them into different things (Jonathan, age bracket 46-55).
The quotes above highlight that consumers do not associate the melting of fine metals with the concept of recycling or sustainable consumption. This is not to say that fine jewellery consumption and sustainability are incompatible per se, but rather that consumers are not currently thinking of redesigned jewellery as recycled. In other words, participants are not in a position to make judgements about how fine jewellery and sustainable consumption can work together, even though they reported recycling various materials (e.g. paper, plastics and cans) in their everyday routine practices. This resonates with Rettie et al.'s (2012) claim that consumers associate ethical attributes and behaviours with some product categories but not others. However, our findings go further as they suggest that the lack of explicit thinking about ethical attributes in relation to jewellery is not just due to the product category per se, but rather due to a lack of consumer understanding regarding how 'recycling' old jewellery can benefit the environment as a consequence of old jewels not being thrown away. For example, Jill admits to not considering the possibility of recycling jewellery until learning about it through a friend:

Obviously you see adverts on the television about recycling gold, but also I remember when [my friend] had some of her mum's jewellery recycled into a ring and before then I would never have considered doing that, just because I wouldn't have known it was possible I don't think, so that's kind of made me think about, oooh, you know, you can do that (Jill, age bracket, 36-45).

Therefore, while the example of the conflict-free diamond concerned the emergence of the diamond ring coupled with an ethical attribute (i.e. conflict-free), the example of redesigned jewellery (such as heirlooms and keepsakes) entails the appropriation of an old fine jewellery object which is reintegrated into the consumer's current consumption and usage, and which entails the unintended performance of recycling (Fig. 2). The nature of this behaviour has the potential to extend positive outcomes beyond the act of recycling itself to a wider environmental impact. If a consumer recycles their old jewellery they are potentially less likely to purchase a completely new piece, consequently minimising the negative environmental impact created in the production process of a new fine jewellery item.

Participants also value 'recycled' old jewellery due to the symbolic and emotional significance of such objectsrelevant teleoaffective structures (Schatzki 2001b; Arsel and Bean 2013) —as illustrated through the example of another female participant: 
I like fashion. I like to change my jewellery, so sometimes I put things away in a box because it's not fashionable anymore... You change as you get older, so you change and you want more classical type pieces and you think, oh, I'm going to wear my diamond earrings all the time... I think you get your favourites with jewellery and I think that is because somebody's bought it for you or it means something... At the BJQ, the last time I bought something from there was probably about four years ago and I had something re-modelled. I took a diamond... A necklace which had a diamond in it, and a ring which I didn't wear, which had diamonds in it, and I just had it made into something that I could wear all the time. It wasn't particularly for a special occasion, no, no... I wanted something specifically made to my taste and design that umm... Most jewellery shops that you go to, they don't have the facility to actually make something for you and they kind of want to sell you something that they've already got in stock, so the BJQ is somewhere where they can melt it down and re-make, re-model. But it is a mixture of maybe different jewellery, so it is specific then to you, so you've got a ring, a wedding ring, you've got your grandma's ring or you've got your Auntie's ring, or whatever, you know... As long as it's gold, they'll put it together, but they can't really stamp it, so you might have 18 carat, 9 carat or whatever. They'll mix it for you whereas you don't tend to find [other] jewellery places that will do re-modelling and remaking for you... They do tend to be expensive, because everything has sentimental value to you, but made into something that you'll actually wear (Tamira, 46-55 age bracket).

Through Tamira's quote above, we can convey the performative reintegration process (Magaudda 2011) of old jewellery into consumers' fine jewellery consumption practice. When looking at the redesigned jewellery piece through our extended version of Magaudda's (2011) circuit of practice framework (Fig. 2), we begin with our participants' new aesthetic requirements (i.e. new designs for their old fine jewellery pieces-step 1), which in turn also lead to a depreciation of the use value of such pieces (as consumers acquired them through different life stages and as gifts-step 2). However, such old jewellery retains the emotional and symbolic value of when the piece was first bought or received. This sense of loss of use value then leads consumers to acquire new shared knowledge and understanding (i.e. how to get their old jewellery redesigned and unintentionally recycled, with knowledge of hallmarking also involved-step 3), and which arises as participants engage with and experience the BJQ as their remodelling and consumption place (Everts et al. 2011; Warde 2014). In this process, participants acquire new capabilities (i.e. in fine jewellery redesign commissions and the actual redesigned object-step 4). This nexus of activities highlights the importance of the consumption place or environment in steering behaviour (Warde 2014; Everts et al. 2011), which in turn indicates the potential for the consumption place and retail space to play a role in nudging consumers towards ethical fine jewellery purchasing practice.

As a result of acquiring the redesigned object, we also see a renewal of the meanings and emotional attachment originally linked to the old jewellery piece when it was first bought or received (as the redesigned piece regains its use value in the minds and bodies of consumers due to its upto-date, aesthetically appealing redesign-step 5). In this way, we see a process of reintegration of the redesigned fine jewellery piece into everyday use (step 6), where recycling is just an unintended element of a wider fine jewellery consumption practice entailing an organised nexus of activities, material objects, meanings, sayings and competencies (Røpke 2009). These examples illustrate how the BJQ is conducive of norms, shared knowledge and understanding, as the place for redesigning fine jewellery. These examples also confirm the importance of extending Magaudda's (2011) framework to include such elements within the circuit of practice, particularly in the context of fine jewellery purchases.

\section{Conclusion and Implications}

This paper addresses relevant knowledge gaps as it builds on previous research in the area of ethical consumption and CSR, and explores the ways in which UK consumers' ethical concerns are integrated into the high-involvement, luxury purchase practice of fine jewellery. The paper begins by providing contextual background on the CSR issues currently facing the jewellery industry and by problematizing the extent to which ethics is salient to consumers in relation to their fine jewellery consumption practices. The paper then reviews relevant literature on ethical consumption and its challenges, as well as significant work in relation to ethical issues in luxury consumption. By drawing on theories of practice (Warde 2014; Røpke 2009; Schatzki 1990, 1997, 2001a, b; Warde 2005), and particularly on our extended circuit of practice framework based on Magaudda's (2011) work, we discuss our interpretive consumer research findings with a specific focus on purposefully selected extended narratives of fine jewellery consumption practice. This discussion is framed around two main objects (i.e. the conflict-free diamond ring and redesigned fine jewellery), which illustrate the 
dynamics of elements within the fine jewellery consumption practice; that is, object, doing and meaning, as well as norms, shared knowledge and understanding, and experience of the consumption environment or place (Everts et al. 2011; Warde 2014). In so doing, we analyse whether and how consumers' ethical performativity takes place in the practice of fine jewellery consumption, which can be intentional in relation to some objects as seen in Fig. 1 and its illustration of the extended circuit of practice of a conflict-free diamond ring. However, such consumer intentionality regarding ethics was more the exception than the norm and cannot be seen in relation to other objects, as demonstrated through Fig. 2 and its articulation of the process of reintegration of old jewellery into the extended circuit of fine jewellery consumption practice through unintended recycling and purposeful redesign. Thus, our findings and discussion provide an analysis of intentional and less intentional ethical consumer performances (Everts et al. 2011), within the interconnected nexus of activities of consumers' fine jewellery consumption practice, where meanings, understandings and intelligibility of social phenomena are worked through the various activities that shape such a practice (Schatzki 1997, 2001b).

Our extended circuit of practice analysis of fine jewellery consumption conveys that consumers' ethical and non-ethical performances are very much embedded in social processes whereby "changes in the materiality are part of a more general performative integration where objects, feelings, personal experiences, cultural values and activities" as well as norms, shared knowledge and understanding, and the consumption place "are constantly involved in a process of mutual co-sharing and co-evolution" (Magaudda 2011, p. 31). This means that any attempts to make fine jewellery pieces more ethical through a change in product features that include ethical and sustainability attributes will only work if the ways of co-constructing the ethical meanings of these CSR-compatible objects become more central to the nexus of activities and all other elements within the fine jewellery consumption practice-especially within the place of consumption. This is because fine jewellery consumption is at once material and immaterial; object-related as well as symbolically and emotionally oriented, and traversed by a number of embodied social processes (including the consumption environment and place) which may or may not intersect with consumers' everyday ethical performances in other areas of their lives.

Therefore, our study's first contribution is that, on a practical level, it highlights that if ethics and sustainability are to be embedded in fine jewellery consumption practices, they must be an intrinsic part of the organisation of the social and material environment of trading places and the consumption environment (Warde 2005; Evans et al. 2012); that is, through organising environments such as the BJQ in ways that are
CSR-oriented, rather than eliding responsibility cues and avoiding discussions about ethical issues in fine jewellery production in order not to raise consumer suspicion about potential jewellery supply chain issues (Rainer 2013). Social norms and consumer meanings must also be steered toward creating the link between the symbolic and affective dimensions of fine jewellery consumption, and the ethical performances already undertaken in other realms of consumers' everyday lives, such as commitment to Fairtrade consumption and recycling, which are now so widely adopted and have the potential to 'fit' within the practices of fine jewellery consumption. As a practical example, this can be done by gaining the commitment and support of relevant trade associations and certification bodies, as well as retailers such as those SMEs and designer-makers present in the BJQ, with a view to tackling both the material aspects of ethics in jewellery pieces and jewellery design, as well as point-of-purchase communications that can create the ethically oriented, symbolic connections between consumers' ethical activities in other practices and fine jewellery consumption practice. Such practical actions could improve the link between CSR and luxury consumption (Janssen et al. 2014). Trade associations and certification organisations could then draft policies that draw on best practice regarding ethical product attributes, ethical jewellery design, ethical retailing and marketing communications, which, combined with regulatory change (European Commission 2013), may help shape the ongoing CSR debates in the global fine jewellery industry. Together, such actions are more likely to have positive CSR impact than managerial interventions that solely rely on consumer agency.

A second and more theoretical contribution of our work lies in its use of practice theories to frame the analysis of a luxury consumption practice such as fine jewellery purchases. To the best of our knowledge, this is the first paper to examine such issues of consumer ethics by extending the application of theories of practice to luxury consumption. This is significant in that, to date, consumer research using practice theories has focused mainly on low-involvement, routine and habitual practices. Additionally, in drawing on the conflict-free diamond and the redesigned jewellery objects as examples, we see that practices consist of both routinized and intentional actions, as well as many other elements that are, to varying degrees, intentional or routinized (Everts et al. 2011). Therefore, the application of practice theories to examine luxury consumption practices can open up new areas of inquiry within consumer research, which in turn have the potential to lead to new understanding of luxury consumption and consumer ethics.

A final theoretical contribution of this paper is our extension of Magaudda's (2011) circuit of practice framework and its application to fine jewellery consumption practice. Our extended circuit of practice framework builds 
on Magaudda's framework through additional practice theories, which in turn enables the various elements of fine jewellery purchasing practices to be brought to the fore in an interconnected way. Theory-development emerges through our research as we illustrate the complex interconnections between different practices (Warde 2005), as well as the interrelatedness among object, doing and representations (Schatzki 1997), as in Magaudda's (2011) work. However, our extended framework unpicks fine jewellery purchases; it further emphasises the relevance of norms, shared knowledge and understanding, teleoaffective structures (Schatzki 2001b; Arsel and Bean 2013), as well as the importance of the consumption environment and place (Warde 2014), in shaping fine jewellery consumption practice. Through our analysis, we show that new practices such as ethical luxury consumption will likely require an innovation process through which consumers incorporate new meanings, ethical materials and ethical competencies in their pre-established ways of doing things (Røpke 2009) in relation to luxury consumption. We acknowledge the limitations of our research in relation to the qualitative nature of the methods and small sample size used, of course. Nevertheless, we would encourage future research in this area, particularly studies using complementary in-depth qualitative methods such as participant observation, or quantitative studies seeking to further explore and validate our findings. We would also advocate broader cross-cultural investigations of ethical luxury consumption, given recent studies indicating culturally diverse luxury purchasing practices (Amatulli et al. 2015; Yau and Davies 2014). Additionally, future research could look to investigate the potential for jewellery retailers to improve their revenues and profits through the recommendations provided in this paper. We acknowledge there is a tension within CSR between social and economic goals, and to focus only on the financial benefits to be gained from a more ethical and socially responsible approach to jewellery would be to overlook important and emergent social and business values that CSR represents. However, certain sectors of the industry will hesitate to implement ethical business practices without evidence of the potential financial value of 'doing' CSR (Arend 2014).

\section{Compliance with Ethical Standards}

Conflict of Interest The authors declare that they have no conflict of interest.

Open Access This article is distributed under the terms of the Creative Commons Attribution 4.0 International License (http://crea tivecommons.org/licenses/by/4.0/), which permits unrestricted use, distribution, and reproduction in any medium, provided you give appropriate credit to the original author(s) and the source, provide a link to the Creative Commons license, and indicate if changes were made.

\section{References}

Achabou, M. A., \& Dekhili, S. (2013). Luxury and sustainable development: Is there a match ? Journal of Business Research, 66(10), 1896-1903.

Ajzen, I. (1980). The theory of planned behavior. Organizational Behavior and Human Decision Processes, 50(2), 179-211.

Ajzen, I., \& Fishbein, M. (1991). Understanding attitudes and predicting social behavior. Englewood Cliffs, NJ: Prentice-Hall.

Alawdeen, N. (2015). Ethical sourcing regimes should be designed to benefit local communities, and not primarily marketing interests. CIBJO special report, Coloured Stone Commission. Retrieved August 10, 2015 from http://congress2015.cibjo.org/CIBJO\% 20Special\%20Report $\% 202015 \% 20$ (Coloured\%20Stones).pdf

Amatulli, C., Guido, G., \& Nataraajan, R. (2015). Luxury purchasing among older consumers: exploring inferences about cognitive age, status and style motivations. Journal of Business Research, forthcoming.

Arend, R. (2014). Social and environmental performance at SMEs: Considering motivations, capabilities and instrumentalism. Journal of Business Ethics, 125(4), 541-561.

Arsel, Z., \& Bean, J. (2013). Taste regimes and market-mediated practice. Journal of Consumer Research, 39(5), 899-913.

Baden, D., Harwood, I. A., \& Woodward, D. G. (2011). The effects of procurement policies on 'downstream' corporate social responsibility activity: Content analytic insights into the views and actions of SME owner-managers. International Small Business Journal, 29(3), 259-277.

Bamberg, S., \& Möser, G. (2007). Twenty years after Hines, Hungerford, and Tomera: A new meta-analysis of psycho-social determinants of pro-environmental behaviour. Journal of Environmental Psychology, 27(1), 14-25.

Baxter, J., \& Chua, W. F. (2008). Be(com)ing the chief financial officer of an organisation: Experimenting with Bourdieu's practice theory. Management Accounting Research, 19(3), 212-230.

Bazeley, P. (2013). Qualitative data analysis: Practical strategies. London: SAGE.

Beckham, D., \& Voyer, B. G. (2014). Can sustainability be luxurious? A mixed-method investigation of implicit and explicit attitudes towards sustainable luxury consumption. Advances in Consumer Research, 42, 245-250.

Bishop, K. (2014). CMJ focuses on provenance with Just Ask campaign, Professional Jeweller. Retrieved April 1, 2014, from http://www.professionaljeweller.com/article-14349-cmj-focuseson-provenance-with-just-ask-campaign

Boulstridge, E., \& Carrigan, M. (2000). Do consumers really care about corporate responsibility? Highlighting the consumer attitude-behaviour gap. Journal of Communication Management, 4(4), 355-368.

Bray, J., Johns, N., \& Kilburn, D. (2011). An exploratory study into the factors impeding ethical consumption. Journal of Business Ethics, 98(4), 597-608.

Brinkmann, J., \& Peattie, K. (2008). Consumer ethics research: Reframing the debate about consumption for good. Electronic Journal of Business Ethics and Organization Studies, 13(1), 22-31.

Brun, A., Caniato, F., Caridi, M., Castelli, C., Miragliotta, G., Ronchi, S., \& Spina, G. (2008). Logistics and supply chain management in luxury fashion retail: Empirical investigation of Italian firms. International Journal of Production Economics, 114(2), $554-570$.

Bryman, A., \& Bell, E. (2011). Business research methods (3rd ed.). Oxford: Oxford University Press. 
Bucic, T., Harris, J., \& Arli, D. (2012). Ethical consumers among the Millennials: A cross-national study. Journal of Business Ethics, 110(1), 113-131.

Carrigan, M., \& Attalla, A. (2001). The myth of the ethical consumer: Do ethics matter in purchase behaviour ? Journal of Consumer Marketing, 18(7), 560-578.

Carrigan, M., Moraes, C., \& Leek, S. (2011). Fostering responsible communities: A community social marketing approach to sustainable living. Journal of Business Ethics, 100(3), 515534.

Carrigan, M., Moraes, C., \& McEachern, M. (2013). From conspicuous to considered fashion: A harm-chain approach to the responsibilities of luxury-fashion businesses. Journal of Marketing Management, 29(11-12), 1277-1307.

Carrington, M. J., Neville, B. A., \& Whitwell, G. J. (2014). Lost in translation: Exploring the ethical consumer intention-behavior gap. Journal of Business Research, 67(1), 2759-2767.

Cavalieri, G. (2012). A CSR Doctrine for the Jewellery Industry that is Pertinent to our Time. Retrieved January 6, 2013, from http:// www.cibjo.org/index.php?option=com_content\&view=article\& $\mathrm{id}=572$ :a-csr-doctrine-for-the-jewellery-industry-that-is-perti nent-to-our-times \&catid $=37 \&$ Itemid $=252$

Cervellon, M.-C., \& Wernerfelt, A.-S. (2012). Knowledge sharing among green fashion communities online: Lessons for the sustainable supply chain. Journal of Fashion Marketing and Management, 16(2), 176-192.

Chang, M. K. (1998). Predicting unethical behavior: A comparison of the theory of reasoned action and the theory of planned behavior. Journal of Business Ethics, 17(16), 1825-1834.

Charles, G. (2010). Ethics come into fashion. Marketing, February 24, 16.

Chatzidakis, A., Hibbert, S., \& Smith, A. P. (2007). Why people don't take their concerns about fair trade to the supermarket: The role of neutralisation. Journal of Business Ethics, 74(1), 89-100.

Chaudhuri, H. R., \& Majumdar, S. (2006). Of diamonds and desires: Understanding conspicuous consumption from a contemporary marketing perspective. Academy of Marketing Science Review, $2006(11), 1$

Childs, J. (2010). Fair trade gold: A key to alleviating mercury pollution in sub-Saharan Africa. International Journal of Environment and Pollution, 41(3/4), 259-271.

Childs, J. (2014). A new means of governing artisanal and small-scale mining? Fairtrade gold and developments in Tanzania, Resources. Policy, 40, 128-136.

CIBJO. (2007). Believe in me: A jewellery retailer's guide to consumer trust. London: CIBJO.

Cresswell, J. W. (2007). Qualitative inquiry and research design: Choosing among five approaches (2nd ed.). London: Sage.

Crouch, M., \& McKenzie, M. (2006). The logic of small samples in interview-based qualitative research. Social Science Information, 45(4), 483-499.

d'Astous, A., \& Legendre, A. (2005). Understanding consumers' ethical justifications: A scale for appraising consumers' reasons for not behaving ethically. Journal of Business Ethics, 87(2), $255-268$

Danziger, P. N. (2009). Let them eat cake: Marketing luxury to the masses-as well as the classes. Chicago, IL: Dearborn Trade Pub.

Dauriz, L., Remy, N., \& Tochtermann, T. (2014). A multifaceted future: The jewelry industry in 2020. Retrieved on December 4, 2014 from http://www.mckinsey.com/insights/consumer_and_ retail/a_multifaceted_future_the_jewelry_industry_in_2020

Davies, I., Lee, Z., \& Ahonkhai, I. (2012). Do consumers care about ethical-luxury? Journal of Business Ethics, 106(1), 37-51.

De Clercq, D., \& Voronov, M. (2009). Toward a practice perspective of entrepreneurship: Entrepreneurial legitimacy as habitus. International Small Business Journal, 27(4), 395-419.
De Propris, L., \& Wei, P. (2007). Governance and competitiveness in the Birmingham Jewellery District. Urban Studies, 44(12), 2465-2486.

Eagly, A. H., \& Chaiken, S. (1995). The psychology of attitudes. Psychology and Marketing, 12(5), 459-466.

Earthworks. (2010). Tarnished gold: Assessing the jewelry industry's progress on ethical sourcing of metals. Retrieved on February 20, 2014, from http://www.earthworksaction.org/files/publications/ TarnishedGold_FINAL.pdf

Earthworks. (2013). More shine than substance: How RJC certification fails to create responsible jewelry. Retrieved on April 01, 2014, from http://www.earthworksaction.org/files/publications/ More-Shine-Than-Substance-FINAL.pdf

European Commission (2013). Public consultation on a possible EU initiative on responsible sourcing of minerals originating from conflict-affected and high-risk areas'. Retrieved February 17, 2014, from http://trade.ec.europa.eu/consultations/?consul_id=174

European Commission (2014). Regulation of the European Parliament and of the Council setting up a Union system for supply chain due diligence self-certification of responsible importers of tin, tantalum and tungsten, their ores, and gold originating in conflict-affected and high risk areas. Retrieved March 6, 2014 from http://rjc.worketc.com/?SendFile=14a444d7-44d7-424d818d-2e2059a1c7e6 [accessed 6 March 2014].

Echeverri, P., \& Skalen, P. (2013). Co-creation and co-destruction: A practice-theory based study of interactive value formation. Marketing Theory, 11(3), 351-373.

Eckhardt, G., Belk, R. W., \& Wilson, J. A. J. (2014). The rise of inconspicuous consumption. Journal of Marketing Management, 31(7-8), 807-826.

Evans, D., McMeekin, A., \& Southerton, D. (2012). Sustainable consumption, behaviour change policies and theories of practice. In A. Warde \& D. Southerton (Eds.), The habits of consumption (pp. 113-129). Helsinki: Collegium for Advanced Studies.

Everts, J., Lahr-Kurten, M., \& Watson, M. (2011). Practice matters! geographical inquiry and theories of practice. Erdkunde, 65(4), $323-334$.

Fairtrade (2015). Fairtrade Gold 'I Do'. Fairtrade Foundation, London. Retrieved August 10, 2015, from http://ido.fairtrade. org.uk

Ferreira, C. Performing economics with ethical values? The emergence of markets for biodiversity offsets. Economy and Society, forthcoming.

Finisterra do Paço, A. M., \& Raposo, M. L. B. (2010). Green consumer market segmentation: empirical findings from Portugal: Green consumer market segmentation. International Journal of Consumer Studies, 34(4), 429-436.

Fuentes, C. (2014). Green materialities: marketing and the sociomaterial construction of green products: Marketing and the socio-material construction of green products. Business Strategy and the Environment, 23(2), 105-116.

Giddens, A. (1984). The constitution of society: Outline of the theory of structuration. Cambridge: Polity Press.

Gilg, A., Barr, S., \& Ford, N. (2005). Green consumption or sustainable lifestyles? Identifying the sustainable consumer. Futures, 37(6), 481-504.

Godey, B., Pederzoli, D., Aiello, G., Donvito, R., Chan, P., Oh, H., \& Weitz, B. (2006). Brand and country-of-origin effect on consumers' decision to purchase luxury products. Journal of Business Research, 65(10), 1461-1470.

Goreux, L. (2001). Conflict diamonds (No. 13). World Bank, Washington, DC.

Gregory-Smith, D., Smith, A., \& Winklhofer, H. (2012). Emotions and dissonance in 'ethical' consumption choices. Journal of Marketing Management, 29(11-12), 1201-1223. 
Hailes, S. (2015). Cred jewellery sales increase $64 \%$ in Q1 2015, Professional Jeweller. Retrieved May 11, 2015 from http://www. professionaljeweller.com/cred-jewellery-sales-increase-64-inq1-2015/

Han, Y. J., Nunes, J. C., \& Dreze, X. (2013). Signaling status with luxury goods: The role of brand prominence. Journal of Marketing, 74(4), 15-30.

Harvey, M., McMeekin, A., Randles, S., Southerton, D., Tether, B., \& Warde, A. (2001). Between demand and consumption: A framework for research. Centre for Research on Innovation and Competition Discussion Paper, 40.

Hassan, L., Shiu, E., \& Shaw, D. (2015). Who says there is an intention-behaviour gap? Assessing the empirical evidence of an intention-behaviour gap in ethical consumption. Journal of Business Ethics, forthcoming.

Heine, K., \& Phan, M. (2001). Trading-up mass-market goods to luxury products. Australasian Marketing Journal, 19(2), 108-114.

Hilson, G. (2015). Fair trade gold: Antecedents, prospects and challenges. Geoforum, 39(1), 386-400.

Hilton, M. (2011). Consumerism in twentieth-century Britain: The search for a historical movement. Cambridge: Cambridge University Press.

Hines, J. M., Hungerford, H. R., \& Tomera, A. N. (2008). Analysis and synthesis of research on responsible environmental behavior: A meta-analysis. The Journal of Environmental Education, $18(2), 1-8$

Human Rights Watch. (2009). Diamonds in the rough: Human rights abuses in the Marange diamond fields of Zimbabwe. New York: Human Rights Watch.

Jamali, D., Zanhour, M., \& Keshishian, T. (1987). Peculiar strengths and relational attributes of SMEs in the Context of CSR. Journal of Business Ethics, 87(3), 355-377.

Janssen, C., Vanhamme, J., Lindgreen, A., \& Lefebvre, C. (2009). The Catch-22 of responsible luxury: Effects of luxury product characteristics on consumers' perception of fit with corporate social responsibility. Journal of Business Ethics, 119(1), 45-57.

Johannisson, B. (2009). Towards a practice theory of entrepreneuring. Small Business Economics, 36(2), 135-150.

Jordan, S. L. (2015). Arctic circle goes fairtrade with hockley mint, Professional Jeweller, January 20th. Retrieved on March 5th, 2015 from http://www.professionaljeweller.com/article-15550arctic-circle-goes-fairtrade-with-hockley-mint/

Kapferer, J.-N. (2011). The artification of luxury: From artisans to artists. Business Horizons, 57(3), 371-380.

Kendall, J. (2015). Responsible luxury: A report on the new opportunities for business to make a difference. London: CIBJO.

Keynote. (2014). Jewellery and watches market report. London: Key Note Research Ltd.

King, N. (2010). Template analysis. In G. Symon \& C. M. Cassell (Eds.), Qualitative methods and analysis in organizational research: A practical guide. London: Sage.

King, N., \& Horrocks, C. (2014). Interviews in qualitative research. London: Sage.

Kuzel, A. J. (2010). Sampling in qualitative inquiry. In B. Crabtree \& W. L. Miller (Eds.), Doing qualitative research (2nd ed., pp. 33-45). London: Sage.

Kvale, S. (1996). InterViews: An introduction to qualitative research interviewing. London: Sage.

Layton, S. (2015). Conflict minerals, nickel regulation, platinum fineness and chemicals classification under the spotlight, CIBJO Special Report, Precious Metals Commission. Retrieved August 10, 2015 from http://congress2015.cibjo.org/CIBJO\%20Spe cial\%20Report\%202015\%20(Precious\%20Metals).pdf

Lincoln, Y. S., \& Guba, E. G. (1996). Naturalistic inquiry. Beverly Hills, CA: Sage.
Lin-Hi, N., \& Müller, K. (2015). The CSR bottom line: Preventing corporate social irresponsibility. Journal of Business Research, 66(10), 1928-1936.

Magaudda, P. (2011). When materiality "bites back": Digital music consumption practices in the age of dematerialization. Journal of Consumer Culture, 11(1), 15-36.

Makkonen, H., Olkkonen, R., \& Halinen, A. (2013). Organizational buying as muddling through: A practice-theory approach. Journal of Business Research, 65(6), 773-780.

McEachern, M., \& Warnaby, G. G. (2012). Improving customer orientation within the fresh meat supply chain: A focus on assurance schemes. Journal of Marketing Management, 21(1-2), 89-115.

Miles, M. B., Huberman, A. M., \& Saldana, J. M. (2006). Qualitative data analysis: An expanded sourcebook. Thousand Oaks, CA: SAGE.

Mollenhoff, J., Quinn, H., \& Sjogren, I. (2014). Small to mediumsized enterprises (SMEs): Uptake, access and impact of certification in the jewellery supply chain, Graduate Institute of Geneva report for the Responsible Jewellery Council and Richemont. Retrieved August 9, 2015 from http://www.responsi blejewellery.com/files/Sj\%C3\%B6gren_M\%C3\%B6llenhoff_ Quinn_ARS_RJC.pdf

Moraes, C., Carrigan, M., \& Szmigin, I. (2012). The coherence of inconsistencies: Attitude-behaviour gaps and new consumption communities. Journal of Marketing Management, 28(1-2), 103-128.

Moraes, C., Michaelidou, N., \& Meneses, R. W. (2014). The use of Facebook to promote drinking among young consumers. Journal of Marketing Management, 30(13-14), 1377-1401.

Moraes, C., Shaw, D., \& Carrigan, M. (2011). Purchase power: An examination of consumption as voting. Journal of Marketing Management, 27(9-10), 1059-1079.

Murphy, S., \& Patterson, M. (2014). Motorcycling edgework: A practice theory perspective. Journal of Marketing Management, 27(13-14), 1322-1340.

Muskawa, K. (2014). Thematic lessons from the Marikana Miners' Strike in South Africa: A corporate governance perspective. Mediterranean Journal of Social Sciences, 5(2), 63-67.

Nair, C. (2008). The last word. Luxury goods: Ethics out of fashion. Ethical Corporation. Retrieved from http://www.ethicalcorp. com/content.asp?ContentID $=6192$

Nelissen, R. M. A., \& Meijers, M. H. C. (2014). Social benefits of luxury brands as costly signals of wealth and status. Evolution and Human Behavior, 32(5), 343-355.

Newholm, T., Newholm, S., \& Shaw, D. (2008). A history for consumption ethics. Business History,. doi:10.1080/00076791. 2014.935343.

Witness Global. (2011). The truth about diamonds: Conflict and development. London: Global Witness.

Witness, Global. (2014). Coming clean: How supply chain controls can stop Congo's minerals trade fuelling conflict: a report. London: Global Witness.

OECD. (2013). OECD Due Diligence guidance for responsible supply chains of minerals from conflict-affected and high-risk areas (2nd edn). OECD Publishing. Retrieved from http://www.oecdilibrary.org/governance/oecd-due-diligence-guidance-for-respon sible-supply-chains-of-minerals-from-conflict-affected-andhigh-risk-areas_9789264185050-en

Patton, M. (1990). Qualitative evaluation and research methods (pp. 169-186). Beverly Hills, CA: Sage.

Peloza, J., \& Shang, J. (2011). How can corporate social responsibility activities create value for stakeholders? A systematic review. Journal of the Academy of Marketing Science, 39(1), $117-135$. 
Pollard, J. S. (2004). From industrial district to "urban village? Manufacturing, money and consumption in Birmingham's Jewellery Quarter. Urban Studies, 41(1), 173-193.

Pratt, M. G. (2009). For the lack of a boilerplate: Tips on writing up (and reviewing) qualitative research. Academy of Management Journal, 52, 856-862.

Raats, M. M., Shepherd, R., \& Sparks, P. (1995). Including moral dimensions of choice within the structure of the theory of planned behavior. Journal of Applied Social Psychology, 25(6), 484-494.

Rainer, S. (2013). The case for adopting procedures to encourage CSR in the International Jewellery Industry. London: The World Jewellery Confederation (CIBJO) Report.

Reckwitz, A. (2002). Toward a theory of social practices: A development in culturalist theorizing. European Journal of Social Theory, 5(2), 243-263.

Rettie, R., Burchell, K., \& Riley, D. (2012). Normalising green behaviours: A new approach to sustainability marketing. Journal of Marketing Management, 28(3), 420-444.

RJC. (2013a). Responsible Jewellery Council 2013 Annual Progress Report. London: Responsible Jewellery Council. Retrieved February 10, 2014, from http://www.responsiblejewellery.com/ files/RJC-Annual-Report-2013-S.pdf.

RJC. (2013b). Responsible Jewellery Council—Code of practices. London: Responsible Jewellery Council. Retrieved February 27, 2014, from http://www.responsiblejewellery.com/files/RJC_ Code_of_Practices_2013_eng.pdf.

The Co-operative Bank (2012). Ethical consumer markets report 2012. Retrieved November 19, 2013, from http://www.cooperative.coop/PageFiles/416561607/Ethical-Consumer-Mar kets-Report-2012.pdf

Roper, S., Caruana, R., Medway, D., \& Murphy, P. (2009). Constructing luxury brands: Exploring the role of consumer discourse. European Journal of Marketing, 47(3), 375-400.

Røpke, I. (2009). Theories of practice-New inspiration for ecological economic studies on consumption. Ecological Economics, 68(10), 2490-2497.

Saunders, M. N. K., Thornhill, A., \& Lewis, P. (1990). Research methods for business students (5th ed.). Harlow: Financial Times/Prentice Hall.

Schatzki, T. R. (1997). Do social structures govern action? Midwest Studies in Philosophy, 15(1), 280-295.

Schatzki, T. R. (2001a). Practices and actions a Wittgensteinian critique of Bourdieu and Giddens. Philosophy of the Social Sciences, 27(3), 283-308.

Schatzki, T. R. (2001b). Introduction: Practice theory. In T. R. Schatzki, K. Knorr Cetina, \& E. von Savigny (Eds.), The practice turn in contemporary theory. London: Routledge.

Schatzki, T. R. (2013). Practice mind-ed orders. In T. R. Schatzki, K. KnorrCetina, \& E. von Savigny (Eds.), The practice turn in contemporary theory (pp. 43-55). London: Routledge.

Sen, S., \& Crowley, J. (2013). The relevance of stakeholder theory and social capital theory in the context of CSR and SMEs: An Australian perspective. Journal of Business Ethics, 118(2), 413-427.

Sethi, H., \& Glozer, S. (2013) Are diamonds forever? Exploring the creation and maintenance of a market for ethical diamond engagement rings. In 38th annual macromarketing conference. York University, Toronto.

Shaw, D., Grehan, E., Shiu, E., Hassan, L., \& Thomson, J. (2005). An exploration of values in ethical consumer decision making. Journal of Consumer Behaviour, 4(3), 185-200.

Shaw, D. S., Hogg, G., Wilson, E., Shiu, E., \& Hassan, L. (2006). Fashion victim: The impact of fair trade concerns on clothing choice. Journal of Strategic Marketing, 14(4), 423-436.

Shaw, D., McMaster, R., \& Newholm, T. (2015). Care and commitment in ethical consumption: An exploration of the 'attitudebehaviour gap'. Journal of Business Ethics, forthcoming.
Shaw, D., Shiu, E., \& Clarke, I. (2005). The contribution of ethical obligation and self-identity to the theory of planned behaviour: An exploration of ethical consumers. Journal of Marketing Management, 16(8), 879-894.

Shove, E., \& Pantzar, M. (2010). Consumers, producers and practices: Understanding the invention and reinvention of Nordic Walking. Journal of Consumer Culture, 5(1), 43-64.

Shove, E., \& Walker, G. (1992). Governing transitions in the sustainability of everyday life. Research Policy, 39(4), 471-476.

Spaargaren, G., \& Mol, A. P. J. (1992). Sociology, environment, and modernity: Ecological modernization as a theory of social change. Society \& Natural Resources, 5(4), 323-344.

Sparks, P., \& Shepherd, R. (2007). Self-identity and the theory of planned behavior: Assessing the role of identification with 'Green Consumerism'. Social Psychology Quarterly, 55(4), 388-399.

Spence, L. J. (1994). CSR and small business in a European Policy Context: The 5 C's of CSR and Small Business Research Agenda 2007. Business and Society Review, 112(4), 533-552.

Spiggle, S. (2013). Analysis and interpretation of qualitative data in consumer research. Journal of Consumer Research, 21(3), 491-503.

Steinhart, Y., Ayalon, O., \& Puterman, H. (2009). The effect of an environmental claim on consumers' perceptions about luxury and utilitarian products. Journal of Cleaner Production, 53, 277-286.

Terjesen, S., \& Elam, A. (2012). Transnational entrepreneurs' venture internationalization strategies: A practice theory approach. Entrepreneurship Theory and Practice, 33(5), 1093-1120.

Thøgersen, J., \& Crompton, T. (2009). Simple and painless? The limitations of spillover in environmental campaigning. Journal of Consumer Policy, 32(2), 141-163.

Truong, Y., \& McColl, R. (2011). Intrinsic motivations, self-esteem, and luxury goods consumption. Journal of Retailing and Consumer Services, 18(6), 555-561.

Tynan, C., McKechnie, S., \& Chhuon, C. (2010). Co-creating value for luxury brands. Journal of Business Research, 63, 1156-1163.

Veblen, T. (1912). The theory of the leisure class (2nd ed.). New York: Macmillan.

Vermeir, I., \& Verbeke, W. (2006). Sustainable food consumption: Exploring the consumer "Attitude-Behavioral Intention" Gap. Journal of Agricultural and Environmental Ethics, 19(2), 169-194.

Warde, A. (2005). Consumption and theories of practice. Journal of Consumer Culture, 5(2), 131-153.

Warde, A. (2013). Sustainable consumption and behaviour change. Discover Society. Retrieved November 27, 2013, from http:// www.discoversociety.org/sustainable-consumption-and-beha viour-change/

Warde, A. (2014). After taste: Culture, consumption and theories of practice. Journal of Consumer Culture, 14(3), 279-303.

Weiskopf, R., \& Willmott, H. (2013). Ethics as critical practice: The "Pentagon Papers", deciding responsibly, truth-telling, and the unsettling of organizational morality. Organization Studies, 34(4), 469-493.

Wheeler, K. (2012). The practice of Fairtrade support. Sociology, 46(1), 126-141.

Wiedmann, K.-P., Hennigs, N., \& Siebels, A. (2009). Value-based segmentation of luxury consumption behavior. Psychology and Marketing, 26(7), 625-651.

Yau, A., \& Davies, I. (2014). Exploring the role of modern Confucian values for promoting sustainable consumption in China. In 39th annual macromarketing conference. Royal Holloway University of London, London. 